\title{
Leifsonia aquatica
}

National Cancer Institute

\section{Source}

National Cancer Institute. Leifsonia aquatica. NCI Thesaurus. Code C86491.

A species of aerobic, Gram positive, rod shaped, coryneform bacteria assigned to the phylum Actinobacteria. This species is motile by long peritrichous flagella, catalase and oxidase positive, produces yellow colonies and hydrolyzes starch. L. aquatica is an opportunistic pathogen in immunocompromised patients. 